\title{
THE INFLUENCE OF POLISH ACCESSION TO THE EUROPEAN UNION ON THE TOURIST FLOW IN KRAKOW
}

\author{
J. Gałka, K. Augustowski \\ Jagiellonian University \\ Krakow, Poland
}

\begin{abstract}
The aim of the study was to show impact of touristic development for the Krakow. Krakow is one of the most important city in Poland. Every year it is visited by the thousands of people. After enlargement Poland to European Union, dynamic growth of coming tourists from abroad can be observed. We also discovered that every year Krakow get billions of money from this sector. It is very important to make more investment for this.
\end{abstract}

Key words: Krakow, tourism, tourists in Krakow.

\section{INTRODUCTION}

Krakow is one of the most visited cities in Poland. Its history, numerous monuments and a unique atmosphere, make it attract an increasing number of tourists, year by year. It is no wonder that the tourism industry is very important for further development of the city.

The purpose of this article is an attempt to determine the effect of Polish accession to the European Union on the development of tourism in Krakow. To achieve this goal, certain statistical data have been analyzed, ie. on the volume of tourist traffic in the city and on the financial income from tourism in the past few years.

\section{PREVIOUS RESEARCH AND AIM OF THE STUDY}

Tourism studies are invaluable in monitoring the development of the tourism industry. Until now, there have been written a number of papers describing various aspects of tourism. Narrowing the area of research to Krakow, it can be concluded that most of the work on the development of tourism in the city has been written by a group of people united in Malopolska Tourist Organization. Among the main studies on the development of tourism are works of Borkowski et al. (2003, 2009a, 2009b, 2009c), Seweryn (2005, 2008). Worth mentioning are also some studies on development prospects of tourism in Krakow (Dutkowski et al. 2011; Rotter-Jarzębińska, Wilkońska 2007).

A slightly different perspective is presented in a study of Seweryn and Niemczyk (2009), which relates to the quality of tourist services in Krakow.

What lacks in the literature are more recent studies that would relate to the impact of the EU enlargement on the development of tourism in Krakow.

This article attempts to answer the question of the role of the EU enlargement on the development of tourism in Krakow and tries to find measurable benefits of this situation. To achieve this goal, certain statistical data have been analyzed, ie. on the volume of tourist traffic in the city and on the financial income from tourism in the past few years. In the

(c) Gałka J., Augustowski K., 2013 
study there have been used data from the Central Statistical Office and the Malopolska Tourist Organization (MOT).

\section{TOURIST TRAFFIC IN KRAKOW AFTER POLAND'S ACCESSION TO THE EUROPEAN UNION}

Even before the Polish accession to the European Union, Krakow was the main city on the tourist map of Poland. A multitude of monuments connected with Polish history and many cultural events organized in the city, have made it achieve the title of "Polish cultural capital".

However, after Polish accession to the European Union, some changes in tourism occurred on May $1^{\text {st }}$, 2004. It has been noted that the number of tourists visiting the city increased significantly. According to the Malopolska Tourist Organization (MOT) in 2003, the number of tourists in Krakow was 3, 5 million, two years later increased to 5.5 million, and in 2011 reached a value of over 6.5 million (Fig. 1). The analysis of the number of guests visiting the city shows that even higher numbers. In 2004, there were 5.5 million visitors whereas in $2011-8.6$ million. It means there has been an increase of 56\%.

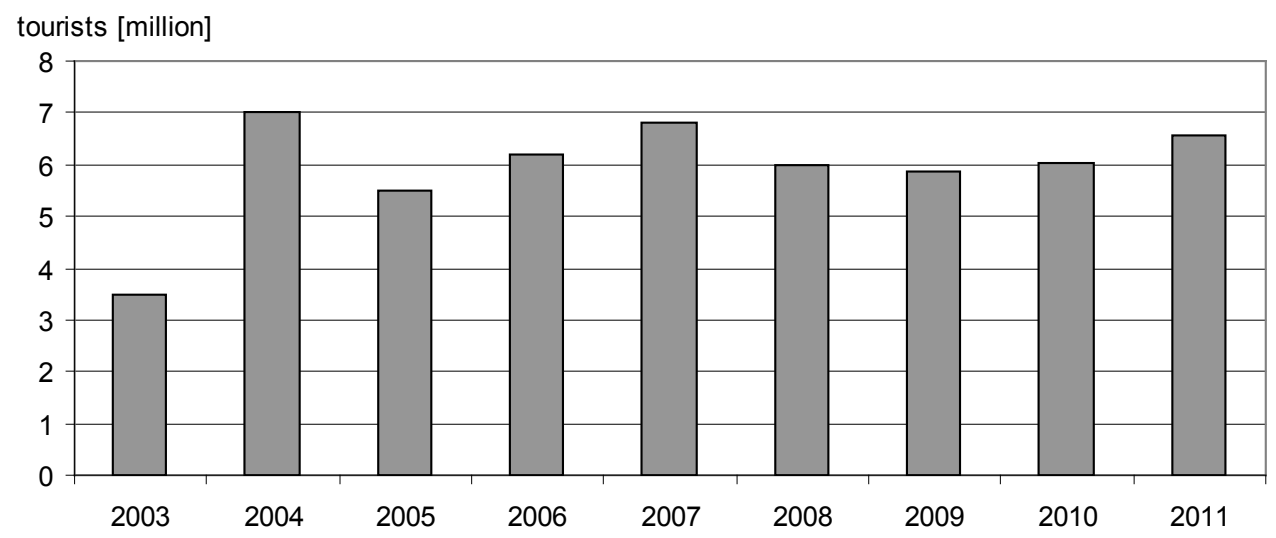

Figure. 1 Total Number of tourists in Krakow in the years 2003-2011

Source: own study based on data from MOT.

During the considered period, the increase in the number of tourists was caused mainly by the inflow of people from abroad, whose share in the total number of tourists was $21.4 \%$ in 2004, and rose up to $31.3 \%$ in 2011 (Fig. 2).

According to the MOT, the main directions of the inflow of foreign tourists to Krakow were the United Kingdom (20\%), Germany (12.6\%), Spain (10.5\%), Italy (9.5\%) and France $(7.5 \%)$. However, among the national tourist, most of them came from areas adjacent to the city, that is, from the provinces: Małopolskie (19.8\%), 11.0\% Ślaskie, Podkarpackie $(10.0 \%)$ and Mazowieckie (8.8\%).

The inflow of foreign tourists to Krakow was due to the development of low-cost airlines and the introduction of the free movement of people between the countries of the European Union. Another factor attracting foreign tourists was not only an extensive tourist offer of Krakow city itself(Old Town, Wawel Castle, Kazimierz, Nowa Huta), but also offers of other 
cities located near Krakow, such as Wieliczka (salt mine), Wadowice (the birthplace of Pope John Paul II), Auschwitz (Nazi concentration camp).

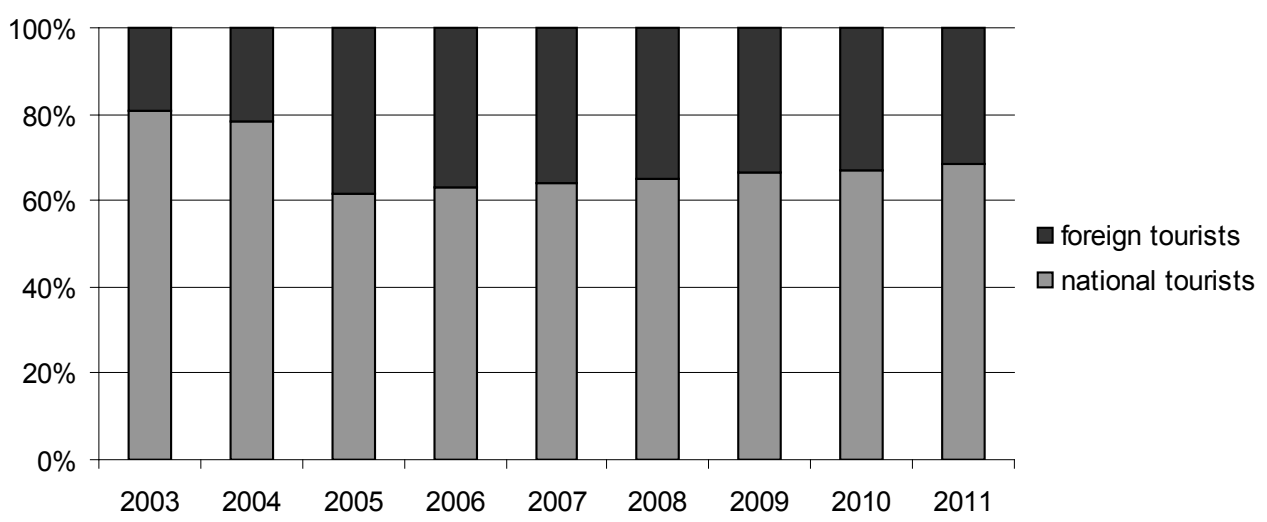

Figure. 2 Structure of origin of tourists visiting the city in the years 2003-2011

Source: own study based on data from MOT.

It is worth noticing, that the number of tourists decreased in 2009. This should be linked to the outbreak of the global economic crisis, especially in Western Europe, from where many people visited Poland in previous years. The reason for decrease in the number of tourists from abroad, may also be a decreasing number of airline connections offered by low-cost airlines.

An important aspect arising from the development of tourism is the number of people buying the accommodation during their stay in Krakow. It turns out, that the number of those people increased steadily after the Polish accession to the European Union (Fig. 3). In 2004, the number of such people was approximately 840 thousands, while in 2011 increased up to 1.63 million.

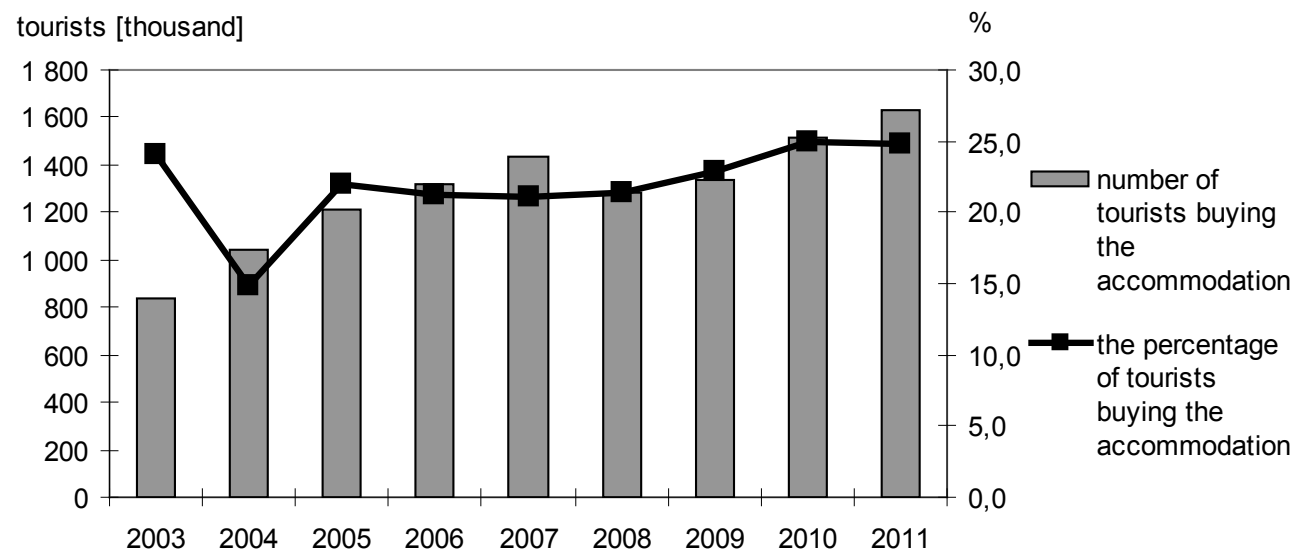

Figure. 3 Number and percentage of tourists buying accommodation in Krakow in the years 2003-2011 
Source: own study based on data from MOT.

\section{FINANCIAL INCOME FROM TOURISM IN KRAKOW}

A measurable result of the tourism development in Krakow, is the financial income. Over the past few years, it has increased several times (Fig. 4). According to the MOT, in 2004, income derived from tourism reached 2.3 billion $\mathrm{zl}$, while in 2010 it increased to 3.5 billion zt. It is worth noticing, that at the same time the city authorities increased the amount of funding for the development and modernization of tourist facilities, as well as the development of tourism. Therefore, Krakow has a chance to make further tourist investment and to remain one of the most visited cities in Poland.

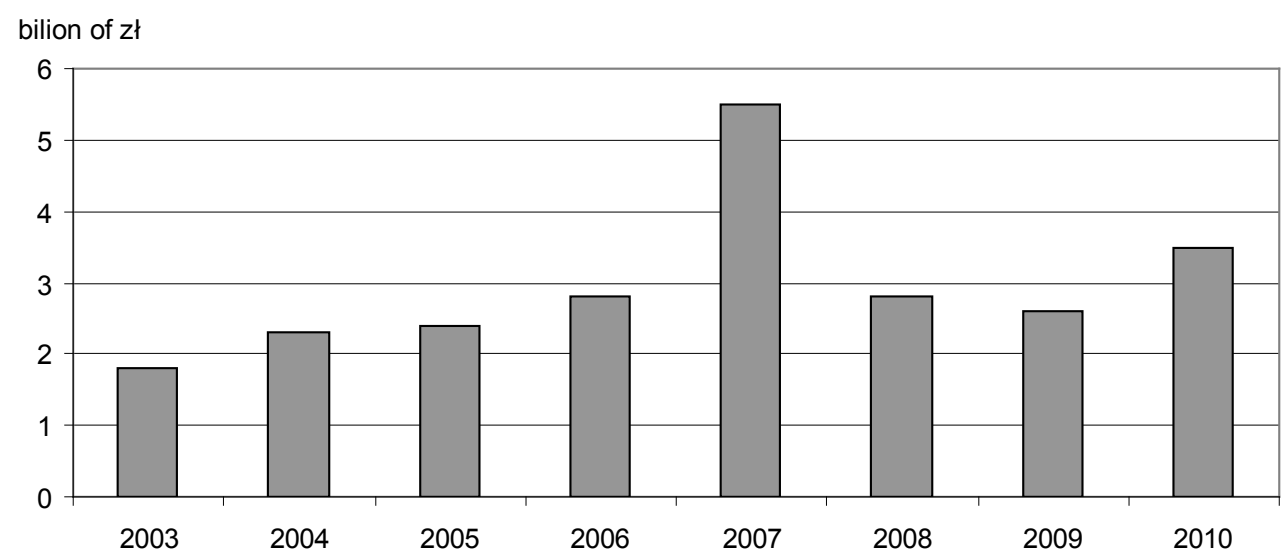

Figure. 4 Financial income from tourism in Krakow in 2003-2010

Source: own study based on data from MOT.

\section{SUMMARY}

Summing up, the present city of Krakow attracts tourists not only from Poland, but also from other European countries and beyond. Polish accession to the European Union certainly contributed to the increase in the number of foreign tourists in the city, which indirectly contributed to the increase in revenue from tourism.

It is worth considering how to even better promote the city abroad and how to upgrade tourist infrastructure. This will attract even more visitors and will result in further development of the city.

\section{LIST OF REFERENCES}

1. Borkowski K., Gut-Mostowy A., Grzywna M., Mazanek L., Pociecha M., Seweryn R., Wilkońska, A., 2003, Ruch turystyczny w Małopolsce w 2003 r. Raport końcowy, Wyd. Małopolska Organizacja Turystyczna, Krakow.

2. Borkowski K., Grabiński T., Mazanek L., Seweryn R., Wilkońska A., 2009a, Monitoring zjawisk turystycznych, jako branżowe narzędzie diagnostyczne na przykładzie badań ruchu turystycznego w Krakowie w latach 2003-2009, conference papers, Polskie Stowarzyszenie Turystyki Warszawa 2009, (in press). 
3. Borkowski B., Grabiński T., Mazanek L., Seweryn R., Wilkońska A., 2009b, Istota zintegrowanych badań ruchu turystycznego-doświadczenia wynikające z realizacji badań ruchu turystycznego w Krakowie i Małopolsce w latach 2003-2009, Ministerstwo Sportu i Turystyki, Polska Organizacja Turystyki, Warszawa, (in press).

4. BorkowskiK., Grabiński T., MazanekL., SewerynR., WilkońskaA., 2009c, Szacowaniewielkości ruchuturystycznegowmieście. Krakowiew latach2006-2007 napodstawiebadańankietowych, conference papers, Uniwersytet Szczeciński, Wyższa Szkoła Ekonomiczno-Turystyczna w Szczecinie, Międzyzdroje.

5. Dutkowski M., Sikora T., Wilkońska A., Rotter K., 2005, Strategia Rozwoju Turystyki w Krakowie na lata 2006-2013, Urząd Miasta Krakowa, Krakow.

6. Niemczyk A., Seweryn R., 2009, Jakość usług tworzących produkt turystyczny obszaru w opinii klientów (na przykładzie Krakowa) [in:] I. Rudawska, M. Soboń (eds.), Przedsiębiorstwo i klient w gospodarce opartej na usługach, Difin, Warszawa, s. 353-361.

7. Rotter-Jarzębińska K., Wilkońska A., 2007 Formy turystyki w Krakowie-stan i perspektywy rozwoju, Wyd. Instytut Geografii i Gospodarki Przestrzennej UJ, Prace Geograficzne, 117, $125-140$.

8. Seweryn R., 2005, Uczestnicy turystyki religijno-pielgrzymkowej w Krakowie (w oparciu o wyniki badań ruchu turystycznego) [in:] I. Milewska (ed.) Turystyka religijnopielgrzymkowa, conference papers, Wyższa Szkoła Turystyki i Hotelarstwa w Gdańsku, Gdańsk, 299-311.

9. Seweryn R., 2008, Satysfakcja turysty a jego lojalność wobec obszaru recepcji turystycznej (na podstawie wyników badań ruchu turystycznego w Krakowie) [in:] G. Sobczyk (ed.) Współczesny marketing. Trendy. Działania, PWE, Warszawa, 524-530. 


\title{
ВПЛИВ ПРИЄДНАННЯ ПОЛЬЩ ДО ЄВРОПЕЙСЬКОГО СОЮЗУ НА ТУРИСТИЧНІ ПОТОКИ У КРАКОВІ
}

\author{
Я. Галка, К. Августовський \\ Ягеллонський університет \\ Краків, Польща
}

Мета дослідження полягала в тому, щоб показати вплив туристичного розвитку для Кракова. Краків є одним з найважливіших міст у Польщі. Щороку його відвідують тисячі людей. Після вступу Польщі до Європейського Союзу, можна спостерігати динамічне зростання приїжджаючих туристів з-за кордону. Ми також виявили, що з кожним роком Краків отримує мільярди грошей з цього сектора. Це дуже важливо для розвитку міста.

Ключові слова: Краків, туризм, туристи у Кракові.

\section{ВЛИЯНИЕ ПРИСОЕДИНЕНИЯ ПОЛЬШИ К ЕВРОПЕЙСКОМУ СОЮЗУ НА ТУРИСТИЧЕСКИЕ ПОТОКИ В КРАКОВЕ}

\author{
Я. Галка, К. Августовский \\ Ягеллонский университет \\ Краков, Польша
}

\begin{abstract}
Цель исследования состояла в том, чтобы показать влияние туристического развития для Кракова. Краков является одним из важнейших городов в Польше. Ежегодно его посещают тысячи людей. После вступления Польши в Европейский Союз, можно наблюдать динамичный рост приезжающих туристов из-за границы. Мы также обнаружили, что с каждым годом Краков получает миллиарды денег из этого сектора. Это очень важно для развития города.

Ключевые слова: Краков, туризм, туристы в Кракове.
\end{abstract}

